\title{
PENENTUAN NILAI SPF (SUN PROTECTION FACTOR) DARI EKSTRAK ETANOL PROPOLIS SECARA IN VITRO UNTUK PENGGUNAAN SEBAGAI TABIR SURYA PADA WANITA
}

\section{DETERMINATION OF SPF (SUN PROTECTION FACTOR) VALUE FROM ETHANOL EXTRACTS OF PROPOLIS BY IN VITRO AS SUNSCREEN FOR THE WOMEN}

\author{
Santi Sinala ${ }^{1}$, Alfrida Monica Salasa ${ }^{2}$ \\ 1,2Jurusan Farmasi Poltekkes Kemenkes Makassar \\ *) Koresponden : santisinala@poltekkes-mks.ac.id
}

ABSTRAK

\begin{abstract}
Matahari merupakan sumber radiasi terbesar yang ada. Selain sinar matahari mengandung spectrum yang dapat mengubah senyawa menjadi vitamin $\mathrm{D}$, terdapat pula spectrum dari sinar matahari yang berbahaya bagi kesehatan kulit. Hal ini dapat menyebabkan kerusakan pada kulit seperti kulit kusam, kulit bintik-bintik hitam, bahkan bisa terjadi kanker kulit. Hal-hal inilah yang menjadi salah satu factor yang menganggu kesehatan. Matahari memiliki spektrum Ultraviolet A (UV A) dan Ultraviolet B (UV B). Telah dilakukan penelitian dalam penentuan nilai SPF dari ekstrak etanol propolis. Penelitian ini merupakan penelitain eksperimental. Ekstrak propolis diperoleh dengan cara maserasi bertingkat menggunakan pelarut $n$-heksan kemudian dilanjutkan dengan pelarut etanol $70 \%$. Ekstrak kental didapat setelah hasil ekstraksi dirotapavor dan dimasukkan ke Frezze dyer. Ekstrak etanol dibuat dalam beberapa seri pengenceran $400 \mu \mathrm{g} / \mathrm{ml}, 800 \mu \mathrm{g} / \mathrm{ml}, 1200 \mu \mathrm{g} / \mathrm{ml}, 1400 \mu \mathrm{g} / \mathrm{ml}, 1600 \mu \mathrm{g} / \mathrm{ml}, 1800 \mu \mathrm{g} / \mathrm{ml}$ dan $2000 \mu \mathrm{g} / \mathrm{ml}$, yang kemudian diukur absorbansinya menggunakan spektrofotometer visible pada panjang gelombang $290 \mathrm{~nm}-340 \mathrm{~nm}$ dengan interval $5 \mathrm{~nm}$. Hasil yang diperoleh adalah pada konsenrasi $400 \mu \mathrm{g} / \mathrm{ml}$ memiliki nilai SPF 2,8, konsentrasi $800 \mu \mathrm{g} / \mathrm{ml}$ dengan nilai SPF 6, konsentrasi $1200 \mu \mathrm{g} / \mathrm{ml}$ dengan nilai SPF 10, konsentrasi $1400 \mu \mathrm{g} / \mathrm{ml}$ dengan nilai SPF 12 , konsentrasi $1600 \mu \mathrm{g} / \mathrm{ml}$ dengan nilai SPF 14, konsentrasi $1800 \mu \mathrm{g} / \mathrm{ml}$ dengan nilai SPF 16 dan $2000 \mu \mathrm{g} / \mathrm{ml}$ dengan nilai SPF 18. Nilai-nilai ini menunjukkan bahwa ekstrak etanol memiliki tingkat proteksi minimal pada konsentrasi $400 \mu \mathrm{g} / \mathrm{ml}$ dan tingkat proteksi ultra pada konsentrasi $1800 \mu \mathrm{g} / \mathrm{ml}$.
\end{abstract}

Kata Kunci : Propolis, Ekstrak Etanol, SPF

ABSTRACT

The sun is the largest source of radiation. In addition to sunlight containing a spectrum that can convert compounds into vitamin $D$, there is also a spectrum of sunlight that is harmful to skin health. This can cause damage to the skin such as dull skin, skin black spots, skin cancer can even occur. These things are one of the factors that disturb health. The sun has a spectrum of Ultraviolet A (UV A) and Ultraviolet B (UV B). Research has been carried out in determining the SPF value of propolis ethanol extract. This research is an experimental research. Propolis extract was obtained by multilevel maceration using $n$-hexane solvent then continued with $70 \%$ ethanol solvent. Thick extract was obtained after the extraction was rotated and put into Frezze dyer. The ethanol extract was made in several series of diluted were $400 \mu \mathrm{g} / \mathrm{ml}, 800 \mu \mathrm{g} / \mathrm{ml}, 1200 \mu \mathrm{g} / \mathrm{ml}, 1400 \mu \mathrm{g} / \mathrm{ml}, 1600 \mu \mathrm{g} / \mathrm{ml}, 1800 \mu \mathrm{g} / \mathrm{ml}$ and $2000 \mu \mathrm{g} / \mathrm{ml}$, which then absorbance was measured using a spectrophotometer visible on wavelength $290 \mathrm{~nm}-340 \mathrm{~nm}$ at intervals of $5 \mathrm{~nm}$. The results obtained were at concentration of $400 \mu \mathrm{g} / \mathrm{ml}$ having SPF value of 2.8 , at concentration of $800 \mu \mathrm{g} / \mathrm{ml}$ with SPF 6 value, at concentration of $1200 \mu \mathrm{g} / \mathrm{ml}$ with SPF 10 value, at concentration of $1400 \mu \mathrm{g} / \mathrm{ml}$ with SPF 12 value, at concentration of $1600 \mu \mathrm{g} / \mathrm{ml}$ with SPF 14 value, at concentration of $1800 \mu \mathrm{g} / \mathrm{ml}$ with SPF 16 and at concentration of $2000 \mu \mathrm{g} / \mathrm{ml}$ values with SPF value 18. These values indicate that ethanol extract has a minimum level of protection at a concentration of $400 \mu \mathrm{g} / \mathrm{ml}$ and ultra protection level at concentration of $1800 \mu \mathrm{g} / \mathrm{ml}$.

Keyword : Propolis, Ethanol extract, SPF

\section{PENDAHULUAN}

Ibu sebagai seorang wanita dengan tekstur kulit yang mudah terkena radiasi dari sinar matahari. Hal ini dapat menyebabkan kerusakan pada kulit seperti kulit kusam, kulit bintik-bintik hitam, bahkan bisa terjadi kanker kulit. Hal-hal inilah yang menjadi salah satu factor yang menganggu kesehatan.
Sinar matahari merupakan sumber energi yang berperan penting bagi kehidupan makhluk di bumi. Namun, disamping efek yang menguntungkan, paparan sinar matahari yang melimpah dengn intensitas yang tinggi dapat menyebabkan hiper-pigmentasi kulit sehingga kulit menjadi kusam dan bersisik bahkan dapat meningkatkan risiko kanker kulit. Kaur dan Saraf (2009) 
mengemukakan paparan berlebihan dapat menyebabkan kerusakan fotokimia pada DNA sel sehingga memicu pertumbuhan kanker kulit.

$$
\text { Umumnya kulit memiliki }
$$

mekanisme pertahanan terhadap efek toksik paparan sinar matahar, seperti pengeluaran keringat, pembentukan melanin, dan penebalan sel tanduk. Akan tetapi, penyinaran yang berlebihan terhadap system perlindungan tersebut tidak mencukupi lagi karena banyak pengaruh lingkungan yang secara cepat atau lambat dapat merusak jaringan kulit. Oleh karena itu diperlukan perlindungan kulit tambahan dengan dibuatnya sediaan kosmetika pelindung kulit yaitu sunscreen yang mengandung senyawa tabir surya yang bekerja melindungi kulit dari radiasi UV secara langsung (Wilkinson \& Moore, 1982).

Salah satu sumber bahan baku adalah dari hewan. Lebah adalah hewan yang banyak menghasilkan produk untuk pengobatan, diantaranya madu dan propolis. Propolis dikumpulkan oleh lebah dari tumbuh-tumbuhan atau pucuk muda dan kulit pohon terutama pohon poplar lalu dicampurkan dengan air liurnya, yang digunakan untuk menambal lubang dalam sarang lebah yang sekaligus juga melindungi sarang lebah dari serangan virus, bakteri dan jamur (Ghisalberti et al., 1978).

Salah satu penelitian telah peneliti lakukan yaitu penentuan total polifenol dan total flavonoid terhadap ekstrak etanol propolis pada tahun 2016. Penelitian ini menjelaskan bahwa ekstrak etanol mengandung senyawa flavonoid dan senyawa polifenol dengan kadar yang cukup banyak. Kedua senyawa ini dapat menjadi bahan tabir surya seperti zink oksida (Hartono, 2018), sebagai penahan sinar ultraviolet karena adanya gugus kromofor pada kedua senyawa tersebut.

Melihat uraian di atas maka akan diuji aktivitas ekstrak etanol propolis sebagai tabir surya berdasarkan besarnya nilai SPF (Sun Protection Factor) dengan menggunakan spektrofotometer UV.

Berdasarkan latar belakang di atas maka rumusan masalah adalah bagaimana aktivitas tabir surya dari ekstrak etanol propolis secara in vitro berdasarkan nilai SPF? Sedangkan tujuan penelitian ini adalah menentukan aktivitas tabir surya dari ekstrak etanol propolis beradasarkan nilai SPF

\section{METODE PENELITIAN \\ Desain, tempat dan waktu}

Penelitian ini adalah penelitian observasi menggunakan alat pengukuran yaitu Spektrofotometer UV Vis. Penelitian ini dilaksanakan pada bulan Maret Oktober 2017 di Laboratorium Kimia dan Laboratorium Biologi Farmasi Jurusan Farmasi Poltekkes Kemenkes Makassar.

\section{Alat dan Bahan}

Alat-alat yang digunakan adalah seperangkat alat maserasi, timbangan analitik, rotavapor, penangas air, Freeze Dyer, alat-alat gelas, Spektrofotometer UVVis. Sedangkan Bahan-bahan yang digunakan raw propolis, n-heksan, air suling, etanol $70 \%$, dan etanol $96 \%$.

\section{Penyiapan Sampel}

\section{a. Pengambilan Sampel}

Sampel raw propolis diperoleh dari Fakultas Kehutanan Universitas Hasanuddin pada bulan Juli 2017.

b. Pengolahan Sampel

Raw propolis dimasukkan ke dalam freezer hingga membeku. Setelah membeku, propolis dipotong kecil-kecil dan diserbukkan, lalu diekstraksi.

c. Ekstraksi

Propolis yang telah diserbukkan ditimbang sebanyak 500 gram lalu diekstraksi secara maserasi dengan $\mathrm{n}$-heksan sebanyak satu liter selama $1 \times 24$ jam dengan bantuan magnetik stirer. Proses maserasi diulangi sebanyak lima kali sehingga diperoleh pelarut $\mathrm{n}$-heksan menjadi bening dan residu bebas lemak. Filtrat lalu diuapkan dengan rotavapor hingga diperoleh ekstrak n-heksan kental kemudian dikeringkan di dalam vakum desikator.

Residu hasil ekstraksi nheksan dimaserasi dengan etanol $70 \%$ sebanyak $500 \mathrm{ml}$ selama 1 × 24 jam dengan bantuan magnetik stirer. 
Proses maserasi diulangi sebanyak lima kali. Filtrat lalu diuapkan dengan rotavapor kemudian dikeringkan di freeze dryer sehingga diperoleh ekstrak kental.

\section{Pengukuran Sampel (Penentuan Nilai SPF)}

Dibuat larutan stock $20000 \mu \mathrm{g} / \mathrm{ml}$ dengan melarutkan $100 \mathrm{mg}$ sampel ekstrak etanol propolis sebanyak $50 \mathrm{ml}$ pada labu ukur $50 \mathrm{ml}$ dengan etanol 96\%. Kemudian dibuat pengenceran konsentrasi sampel $400 \mu \mathrm{g} / \mathrm{ml}, 800 \mu \mathrm{g} / \mathrm{ml}, 1200 \mu \mathrm{g} / \mathrm{ml}, 1400$ $\mu \mathrm{g} / \mathrm{ml}, 1600 \mu \mathrm{g} / \mathrm{ml}, 1800 \mu \mathrm{g} / \mathrm{ml}$ dan 2000 $\mu \mathrm{g} / \mathrm{ml}$. Seri larutan kemudian diukur absorbansinya pada panjang gelombang $290 \mathrm{~nm}$ hingga $320 \mathrm{~nm}$ dengan interval panjang gelombang $5 \mathrm{~nm}$

Nilai SPF dihitung dengan rumus di bawah ini (Mansur, 1986)

\author{
$\mathrm{SPF}=\mathrm{Abs} \times(\mathrm{EE} \times \mathrm{I}) \times \mathrm{CF}$ \\ Dimana : \\ Abs = Serapan seri konsentrasi \\ EE = Spektrum efek eritemal \\ I = Intensitas spectrum sinar \\ $\mathrm{CF} \quad=$ Faktor koreksi
}

\section{Analisis data}

Data diolah berdasarkan rumus di atas dan akan ditarik kesimpulan berdasarkan hasil perhitungan.

\section{HASIL}

Dari penelitian ini diperoleh hasil berupa ekstrak yang terdiri dari ekstrak $n$ heksan dan ekstrak etanol. Dimana rendamen yang diperoleh untuk ekstrak nheksn sebanyak $48,6 \%$ dan untuk ekstrak etanol $70 \%$ sebanyak $15,02 \%$. Sedangkan untuk nilai SPF yang diperoleh dapat dilihat pada tabel

Tabel 1. Nilai SPF tiap Konsentrasi

\begin{tabular}{ccccc}
\hline \multirow{2}{*}{ KONSENTRASI } & \multicolumn{3}{c}{ REPLIKASI } & RATA-RATA \\
\cline { 2 - 5 } & $\mathbf{I}$ & II & III & \\
\hline $400 \mu \mathrm{g} / \mathrm{ml}$ & 2.8117 & 2.8158 & 2.8049 & 2.8108 \\
$800 \mu \mathrm{g} / \mathrm{ml}$ & 6.3344 & 6.3621 & 6.3576 & 6.3513 \\
$1200 \mu \mathrm{g} / \mathrm{ml}$ & 9.8802 & 10.2420 & 10.5255 & 10.2159 \\
$1400 \mu \mathrm{g} / \mathrm{ml}$ & 11.9490 & 12.2010 & 12.5398 & 12.2299 \\
$1600 \mu \mathrm{g} / \mathrm{ml}$ & 14.0018 & 14.4101 & 14.0570 & 14.1563 \\
$1800 \mu \mathrm{g} / \mathrm{ml}$ & 16.0030 & 16.6459 & 16.7461 & 16.465 \\
$2000 \mu \mathrm{g} / \mathrm{ml}$ & 18.6107 & 19.7311 & 18.5325 & 18.9581 \\
\hline
\end{tabular}

\section{PEMBAHASAN}

Propolis merupakan suatu bahan alam, dimana propolis adalah kumpulan secret dari lebah. Raw propolis mempunyai konsistensi yang keras, alot seperti getah dan berwarna coklat. Dengan tekstur yang demikian maka terlebih dahulu raw propolis dibekukan di dalam freezer agar mudah untuk dipotong-potong. Maserasi bertingkat dengan pelarut $n$-heksan dan etanol $70 \%$ digunakan dalam mengekstraksi propolis dengan tujuan memisahkan senyawasenyawa non polar yang akan ditarik oleh pelarut $n$-heksan seperti lemak-lemak dan getah. Hal ini terlihat pada rendamen yang dihasilkan oleh pelarut n-heksan dimana beratnya mencapai 1485,80 gram. Sedangkan pelarut etanol $70 \%$ akan menarik senyawa non polar dan polar karena etanol $70 \%$ merupakan pelarut semipolar. Pada penelitian ini ekstrak etanol yang akan ditentukan nilai SPF nya karena pada penelitian sebelumnya, Santi Sinala telah menentukan kadar total flavonoid dan total polifenol yaitu 4,69\% dan $6,64 \%$ Kedua senyawa ini sangat berhubungan dengan aktivitas proteksi terhadap sinar matahari. Senyawa flavonoid dan polifenol merupakan senyawa yang memiliki gugus aromatis terkonjugasi dengan gugus para dan orto antara gugus penerima electron $\mathrm{dn}$ gugus pelepas electron sehingga memungkinkan terjadinya delokalisasi dan perpindhan electron dari gugus yang melepaskan electron ke gugus yang menerima electron. 
Perhitungan quantum mekanik menunjukkan bahwa energi delokalisasi electron ini berhubungan dengan energi radiasi pada daerah UV A dan UV B. Senyawa polifenol dapat menstabilkan perpindahan electron sehingga dapat menyerap radiasi sinar UV (Velasco et all.,2008)

SPF atau Sun Protection Factor adalah nilai untuk menunjukkan tingkat proteksi terdapat radiasi UV. Nilai SPF menyatakan berapa lama seseorang aman terpapar oleh sinar matahari. Misalnya jika seseorang memiliki kulit yang tidak dilindungi oleh sesuatu dan jika terpapar oleh sinar matahari menjadi terbakar dalam waktu 5 menit dan sediaan tabir surya dengan SPF 15 membolehkan orang tersebut terpapar sinar matahari selama 15 x 5 menit yaitu 75 menit tanpa terbakar.

Penentuan nilai SPF ditentukan dengan cara pengukuran seri konsentrasi ekstrak etanol propolis menggunakan Spektrofotometer UV Vis pada panjang gelombang $290 \mathrm{~nm}$ - $320 \mathrm{~nm}$ dengan interval $5 \mathrm{~nm}$. Rentang panjang gelombang
$290 \mathrm{~nm}-320 \mathrm{~nm}$ merupakan range sinar UV B. UV A (320 - $400 \mathrm{~nm})$ dan UV C (100 - $290 \mathrm{~nm}$ ). Radiasi UV C secara total diblok oleh lapisan ozon di atmosfir paling atas sebelum mencapai bumi. Radiasi UV B tidak sempurna difilter oleh lapisan ozon dan menyebabkan kerusakan kulit hingga kulit menjadi terbakar.Sedangkan radiasi UV A semuanya melewati lapisan ozone. Terpapar radiasi UV mencapai lapisan terdalam dari epidermis dan dermis yang dapat merusak keelastisan dan jaringan kolagen yang menghubungkan jaringan kulit, sehingga dapat menyebabkan penuaan dini (photo-aging).

Dari hasil pengukuran diperoleh bahwa ekstrak etanol propolis pada konsentrasi $400 \mu \mathrm{g} / \mathrm{ml}$ memiliki nilai SPF $2.8 \approx 3$ yang berarti pada konsentrasi tersebut telah memiliki keefektifan kategori proteksi minimal dalam melindungi kulit dari radiasi dan pada konsentrasi $1800 \mu \mathrm{g} / \mathrm{ml}$ memiliki nilai SPF 16 dengan kategori proteksi ultra. Hasil ini berdasarkan tabel di bawah ini

Tabel 2. Keefektifan Tabir Surya Berdasarkan Nilai SPF

\begin{tabular}{cc}
\hline SPF & Kategori Proteksi Tabir Surya \\
\hline $2-4$ & Proteksi minimal \\
\hline $4-6$ & Proteksi Sedang \\
\hline $6-8$ & Proteksi ekstra \\
\hline $8-15$ & Proteksi maksimal \\
\hline$\geq 15$ & Proteksi ultra \\
\hline
\end{tabular}

(Sumber : Wilkinson and Moore, 1982)

\section{KESIMPULAN}

Dari hasil penelitian dapat disimpulkan bahwa ekstrak etanol propolis pada konsentrasi $400 \mu \mathrm{g} / \mathrm{ml}$ memiliki nilai SPF $2.8 \approx 3$ yang berarti pada konsentrasi tersebut telah memiliki keefektifan kategori proteksi minimal dan pada konsentrasi $1800 \mu \mathrm{g} / \mathrm{ml}$ memiliki nilai SPF 16 dengan kategori proteksi ultra.

\section{SARAN}

Dari hasil penelitian ini disarankan untuk diuji cobakan dengan jenis proses ekstraksi yang lain.

Vol. XIV No. 1, Juni 2019

DOI: https://doi.org/10.32382/medkes.v14i1.707

\section{DAFTAR PUSTAKA}

Gebara. E.C.E., Lima. L.A. dan Mayer. M.P.A. 2002. Propolis antimicrobial activity against periodontopathic bacteria. J. Microbiol. vol.33 no.4.

Ghisalberti, E.L.; Jefferies, P.R.; Lanteri, R. and Matisons, J. (1978): Constituents of propolis. Experientia, 34(2): 157-158.

Hartono, Rudy, Agustian Ipa, Aswita Amir, Bambang Wirjatmadi, Ridho Pratama, Ronny Horax, 2018. Improving the Immune Response II- 
10 and Secretory Immunoglobulin A in the Elderly after Getting Synbiotic. Indian Journal of Public Health Research and Development, Vol 9 No. 12 Des 2018.

Mansur, J.S., et al, 1986, Determination of sun protection factor for spectrophotometry. An. Bras.Dermatol., Rio de Janeiro, v.61,p.121-124

Meenakshi D,2013, EMULGEL : A NOVEL APPROACH TO TOPICAL DRUG DELIVERY, International Journal of Pharma and Bio Sciences, Int $\mathrm{J}$ Pharm Bio Sci Jan; 4(1): (P) 847 856

Miorin PL., Levy NCJ., Custodio AR., Bretz WA., Marcucci MC. 2003. Antibacterial activity of honey and propolis from Apis mellifera and
Tetragonisca angustula against Staphylococcus aureus. J. Appl. Microb. 95: 913-920.

Ozen T., Kilic A. 2010. In Vitro Activity of Turkish Propolis Samples Against Anaerobic Bacteria Causing Oral Cavity Infections. Kafkas Univ Vet Fak Derg 16 (2): 293-298

Rahman M., Richardson A and Sofian. 2010. Antibacterial activity of propolis and honey against Staphylococcus aureus and Escherichia coli. Academic Journals. Canada

Wilkinson, J.B \& Moore, R.J, 1982, Harry"s Cosmeticology $\left(7^{\text {th }}\right.$ edition). New York : Chemical Publishing Company, 3, 231-232, 240-241, 248 